O.E. ZASIMCHUK ${ }^{1, *}$, M.G. CHAUSOV ${ }^{2}$, B.M. MORDYUK ${ }^{1, * *}$, O.I. BASKOVA', V.I. ZASIMCHUK ' ${ }^{\prime}$, T.V. TURCHAK ', and O.S. GATSENKO'

' G.V. Kurdyumov Institute for Metal Physics of the N.A.S. of Ukraine, 36 Academician Vernadsky Blvd., UA-03 142 Kyiv, Ukraine

${ }^{2}$ National University of Life and Environmental Sciences of Ukraine, 15 Heroiv Oborony Str., UA-0304 1 Kyiv, Ukraine

* eezas@imp.kiev.ua,**mordyuk@imp.kiev.ua

\title{
FEATURES OF STRAIN HARDENING OF HETEROGENEOUS ALUMINIUM ALLOYS TO ENHANCE THE FATIGUE DURABILITY
}

Heterogeneous aluminium alloys are in demand in the aviation industry, where the ability of the material to withstand fatigue loads is important. The topic of the article is the search for the most experimentally available methods of deformation effect on such materials in order to increase fatigue life. Unfortunately, previous studies were ambiguous due to the large number of factors influencing the fatigue of metal materials under the same type of mechanical load; so, we chose a dynamic load with pulse loading. It turned out that for heterogeneous 2024-T351 and D16CzATW alloys, shock-vibration loading (SVL) applied during static straining prolongs their further fatigue life at a certain magnitude of the deformation during the action of the pulse. For example, for the 2024-T351 alloy at the maximum stress of alternating load $\sigma_{\max }=400 \mathrm{MPa}$, the longest fatigue life should be expected at deformations $\varepsilon_{\mathrm{imp}}=2-4 \%$; and at the maximum stress of alternating (fatigue) loading of $440 \mathrm{MPa}$, it is at $\varepsilon_{\mathrm{imp}}=3-5 \%$. In comparison with the average values of fatigue life of the $\mathrm{D} 16 \mathrm{CzAT}$ alloy in the initial state, fatigue life after processing increases at $\sigma_{\max }=340 \mathrm{MPa}$ alloy by $11.6 \%$, at a stress of $\sigma_{\max }=370 \mathrm{MPa}$, by $18.4 \%$, at a stress of $\sigma_{\max }=400 \mathrm{MPa}$, by $21.2 \%$. The positive effect of long-term exposure after treatment on fatigue life was also noted. The influence of the strengthening phases, such as the nanosize $\Theta-\mathrm{Al}_{2} \mathrm{Cu}$ and $\mathrm{S}-\mathrm{CuAl}{ }_{2} \mathrm{Mg}$ particles, on the separate stages of pre-treatment of alloys and the effects of their quantities on total fatigue durability is investigated by statistical methods of transmission electron microscopy. The great attention is paid to the mechanism of formation of fatigue fracture embryos in the near-surface areas of the samples, for which analytical calculations and the

Citation: O.E. Zasimchuk, M.G. Chausov, B.M. Mordyuk, O.I. Baskova, V.I. Zasimchuk, T.V. Turchak, and O.S. Gatsenko, Features of Strain Hardening of Heterogeneous Aluminium Alloys to Enhance the Fatigue Durability, Progress in Physics of Metals, 22, No. 4: 619-642 (2021) 
experimental method of ultrasonic impact treatment (UIT) are used. It is shown that the use of UIT after SVL does not affect the fatigue life of the 2024-T351 alloy at a fatigue load frequency of $15 \mathrm{~Hz}$, while the single UIT increases fatigue life of the alloy. It is concluded that the use of complex deformation loads accelerates the relaxation processes, which shorten fatigue life.

Keywords: fatigue life, plastic deformation, pulse loading, transmission electron microscopy, heterogeneous aluminium alloys.

\section{Introduction}

Heterogeneous aluminium alloys find wide application because the products have a relatively low weight at sufficiently high strength that is provided by the presence of hardening phases. These properties are in demand in the aviation industry, which is also an important material's ability to resist fatigue loads. Given this, it is clear that an important issue is the ability to increase the fatigue life of the material through the application of scientifically based influencing methods. First of all, it seemed that the fatigue strength and durability of the material directly depends on the strength and deformation ability of this material. There are many attempts to find such dependence. Here are some examples of research in this direction, performed on aviation materials, mainly on aluminium alloys. The work [1] was devoted to the study of the influence of preloads on fatigue resistance of aluminium alloys. Several alloys, mainly 2017A-T3 and S454-0, and the effect on high-frequency impact fatigue and quasi-static loading were investigated. It is shown that the previous durability can increase from $12 \%$ to $30 \%$. Preliminary deformation from $5 \%$ and its growth to $15 \%$ and above increases fatigue durability, thus fatigue strength increases by $50 \%$. In the 2024-T3 alloy, the preliminary plastic deformation of $\sim 10 \%$ increases fatigue life. The disadvantage of the shock load is the fact that it can cause the formation of fatigue cracks, which reduces durability. In the $\mathrm{Al}-\mathrm{Mg}$ alloy, the fatigue strength decreases when the preliminary tensile deformation is less than $\mathbf{1 . 5} \%$ and becomes close to the source material at $4 \%$, i.e., the effect of the previous deformation intervention is negative. The authors concluded that, given the ambiguous effect of deformation intervention on fatigue strength and durability, it is necessary to concentrate the study of the effect of hardening particles present in the studied alloys on these parameters that are.

In [2], the effect of intense local plastic deformation on the fatigue life of alloys 7475-T and 7351 was investigated. The same article also presents the results of studying the effect of deformation on other aluminium alloys, for example, on alloy 2024-T3, in which the durability after deformation increases from $2.67 \cdot 10^{3}$ cycles to failure, to $3.6 \cdot 10^{3}$ cycles. The same paper refers many studies that show a discrepancy in 
the results. However, it follows that fatigue life increases with decreasing surface roughness. Thus, the deformation conditions significantly affect the fatigue life due to the effect on the surface topography. The influence of local plastic deformation on fatigue life and strength has been studied by the authors of many publications on samples with holes of different shapes, different quantities and in different places of the studied samples, for example, [3, 4].

A very important issue for science and practical use of aluminium alloys is the ability to predict the fatigue durability depending on operating conditions. Consideration of some research on this issue is presented below.

In [5] experimental and numerical study of the fatigue life of 2024T351 aluminium alloy has been investigated. For this purpose, mechanical properties of the material are obtained by tensile test. The MansonCoffin-Basquin equation is used to estimate the fatigue life. The specimen surface is photographed using a microscope camera to examine the specimen deformation. The ratio of white to black pixels on the specimen surface that changes during loading is investigated using the image processing method. Changes in the ratio of white to black pixels indicate that material fatigue is associated with the specimen surface. The experiments are strain-controlled and in six different strain amplitudes. Then, by obtaining the amplitude range of elastic and plastic strains in the stress-strain hysteresis loop, the coefficients of the Manson-Coffin-Basquin equation are calculated in a stable cycle. Using these coefficients, the Manson-Coffin-Basquin equation is presented to estimate the fatigue life of the material in amplitude of different strains. A comparison of the results of this equation and the experimental results shows a good agreement.

The effect of solution treatments at high temperatures on the microstructure and fatigue performance of an $\mathrm{Al}-\mathrm{Cu}-\mathrm{Mg}$ alloy was investigated in [6]. Microstructural observation revealed that large secondary phases could be dissolved sufficiently by a strengthening solution at $507^{\circ} \mathrm{C}$ for $20 \mathrm{~min}$ and shortening the solution time at the high temperature would bring about a significant grain refinement. The fatigue test showed that the sample solution at the high temperature for a short time $\left(507^{\circ} \mathrm{C} / 6 \mathrm{~min}\right)$ possessed the lowest fatigue crack propagation (FCP) rates. This was mainly attributed to the combined effect of the reduced large residual secondary phases and the conspicuous grain refinement. Reducing the large secondary phases remaining by the high temperature solution treatment was beneficial to limit the bridging of cracks, and refining the grains with Goss orientation could induce more crack deflection, consequently enhancing the fatigue resistance.

The possibility of predicting the time fatigue crack formation using FEM analysis of the properties of aluminium alloy A5083-0 under 
fatigue loading was considered in [7]. The authors of [8] insist that in predicting fatigue durability it is necessary to consider three phases, of which this durability consists: 1 - crack origin, 2 - stable crack growth, 3 - unstable crack growth. The largest part of durability is about 40$90 \%$ the emergence of crack. The calculations must take into account the structural elements that encourage the emergence of fatigue crack (e.g., localization plasticity) and those elements that resist their spread (e.g., grain boundaries).

The impact of strain hardening of aluminium alloys on their fatigue was considered in work [9]. The authors drew attention to the fact that the fatigue strength of steels equals to about a half of their tensile yield strength, while the strengthened aluminium alloys have different ratio, i.e., just $1 / 3$. The authors attribute this to the localization of plasticity in the zones free of hardening particles in aluminium alloys, which encourages the formation of cracks in these zones during deformation. To prevent this strain localization and to increase fatigue life, it is necessary to focus on the methods allowing formation of a more uniform distribution of the particles.

The authors [10] studied the possibility of increasing fatigue durability of the alloy 2024-T3 under the action of mechanical loads in different directions, which is of great practical importance. By controlling the formation and growth of cracks, it is possible, according to the authors, to predict the fatigue life of the material.

Thus, even a brief review of studies on the problem of increasing the fatigue durability of heterogeneous aluminium alloys shows that the effect of intense plastic deformation on fatigue durability is either insignificant [2] or even negative due to increasing surface relief, which encourages the formation of fatigue cracks [2-4]. The problem of predicting and modelling the fatigue durability does not add optimism either, although such efforts are known. The authors [1] concluded that, given the ambiguous effect of deformation intervention on fatigue strength and durability, the influence of the reinforcing particles present in the studied alloys is necessary to the study first.

Numerous publications on the problem of fatigue, which accounts for up to $90 \%$ of all destruction events during the operation of industrial facilities show that fatigue cracks occur in the surface layer of the material. The above references analysed the fatigue durability affected by the deformation action on the entire volume, without separating the surface layer. Let us consider existing problems of fatigue durability at deformation influence only on a surface layer up to $15-20 \mu \mathrm{m}$ thick. Studies of the last 70 years have shown that this can be done using ultrasound. The beginning of research in this direction can be attributed to the mid50s of last century, when Mason's work was published [11]. Subsequent works in this direction date back to the $1980 \mathrm{~s}-1990$ s of the last century 
[10-20] and the first years of the $20^{\text {th }}$ century [12-14]. Ultrasonic impact treatment (UIT) is carried out by using the impact needles or other devices that transmit an ultrasonic energy pulse to a depth of $10 \mu \mathrm{m}$ to $2 \mathrm{~mm}$. The purpose of the UIT usually consists in the surface hardening and/or reducing the number of pores and cracks, and the surface quality improvement depends on the selected intensity and duration of UIT.

In our opinion, ultrasonic impact treatment is currently the most effective method for strengthening the surface layers of alloy products based on aluminium. However, despite numerous studies trying to increase the fatigue life of aviation aluminium alloys by deforming the source material, the deformation hardening of both the surface layers and the entire volume of the treated samples did not lead to the desired effect. This is due to the fact that the increase in the mechanical strength of alloys is accompanied by an increase in the speed and volume of the relaxation transformation of the structure of alloys, which inevitably has a negative impact on fatigue durability. In particular, it should be noted that aluminium alloys such as D16CzATW and 2024-T3 are multiphase heterogeneous alloys in which, in addition to the aluminium based solid solution, there are reinforcing phases: $\Theta-\mathrm{Al}_{2} \mathrm{Cu}$ and S$\mathrm{CuAl}_{2} \mathrm{Mg}$. Both phases have a more complex crystal lattice than aluminium, which is the reason for their strengthening effect, and a lower melting point, which indicates the possibility of changing their concentration in the alloy under any energy effects. This should be taken into account when analysing the influence of various external factors on the mechanical and physical properties of the alloy. These difficulties have not yet allowed finding an opportunity to apply successfully the strain hardening of multiphase aluminium alloys to increase significantly their fatigue life. However, our previous works it was showed that due to the implementation of dynamic deformation using shock-vibration loading (SVL) and the induced changes in phase composition [19-23] in aluminium alloy 2024-T3 can significantly increase its fatigue life at load frequencies of $15 \mathrm{~Hz}$. We tried to test this effect by increasing the load frequency to $110 \mathrm{~Hz}$ and to identify the conditions under which the use of strain hardening can significantly increase the fatigue life of such a heterogeneous alloy. The results of the experimental study are presented in this article. In addition, the article presents the results and analyses the impacts of either single UIT applied to the surface layer of samples or complex processing carried out in the sequence of SVL followed by UIT on the fatigue characteristics of the alloy 2024-T3.

\section{Material and Methods of Research}

The chemical compositions of the studied aluminium alloys are shown in Tables 1 and 2 (in wt.\%). Mechanical properties of the studied alloys are represented in Tables 3 and 4. Mechanical tests were performed in such 
a way that the processes of deformation and fracture were investigated as part of a mechanical system, which is a structure in the form of three simultaneously loaded parallel elements. The central element of this design includes grips with spherical supports, a strain gauge and a sample of the test material. Two symmetrical side elements include two identical rods, one of which is used as a strain gauge, as well as fragile samples of different minimum diameters (Fig. 1). Under the load of the described structure, at a given deformation (force) on the sample, the satellite samples of fragile samples are destroyed and the test sample is subjected to pulse loading. In this case, the properties of the loading system determine the conditions of deformation of the material during the dynamic redistribution of stresses caused by the destruction of satellite samples.

This type of test is implemented on the basis of a test hydraulic machine $\mathrm{ZD}-100 \mathrm{Pu}$, a characteristic feature of which is a massive movable traverse (weighing $1350 \mathrm{~kg}$ ).

The unit is equipped with a computerized measuring system for conducting and processing test results, which allows you to record up to $100 \mathrm{kHz}$.

Cyclic (fatigue) loading of samples was carried out on a standard installation 'INSTRON-8802' in the mode of 'cyclic stretching' with a frequency of $15 \mathrm{~Hz}$ and a cycle asymmetry $R=0.1$ (Fig. 2).

All studies on the pulsed introduction of force energy into the aluminium alloy due to SVL in this article were conducted on an upgraded test machine $\mathrm{ZD}-100 \mathrm{Pu}$. Studies to assess the fatigue life of aluminium alloys were performed on a resonant test machine RUMUL TESTRONIC

Table 1. The chemical composition of the aluminium alloy 2024-T351 [24]

\begin{tabular}{|c|c|c|c|c|c|c|c|}
\hline $\mathrm{Si}$ & $\mathrm{Fe}$ & $\mathrm{Cu}$ & $\mathrm{Mn}$ & $\mathrm{Mg}$ & $\mathrm{Cr}$ & $\mathrm{Zn}$ & $\mathrm{Ti}$ \\
\hline 0.05 & 0.13 & 4.7 & 0.70 & 1.5 & 0.01 & 0.02 & 0.04 \\
\hline
\end{tabular}

Table 2. The chemical composition of the aluminium alloy D16CzATW (\%) [25]

\begin{tabular}{|c|c|c|c|c|c|c|c|}
\hline $\mathrm{Si}$ & $\mathrm{Fe}$ & $\mathrm{Cu}$ & $\mathrm{Mn}$ & $\mathrm{Mg}$ & $\mathrm{Cr}$ & $\mathrm{Zn}$ & $\mathrm{Ti}$ \\
\hline 0.11 & 0.18 & 4.4 & 0.63 & 1.4 & 0.01 & 0.01 & 0.07 \\
\hline
\end{tabular}

Table 4. Mechanical properties of aluminium alloy D16CzATW [25]

\begin{tabular}{|c|c|c|}
\hline$\sigma_{0.2}, \mathrm{MPa}$ & $\sigma_{s}, \mathrm{MPa}$ & $\delta, \%$ \\
\hline 322 & 452 & 21.5 \\
\hline
\end{tabular}

Table 3. Mechanical properties of aluminium alloy 2024-T3 51 [24]

\begin{tabular}{|c|c|c|c|}
\hline Alloy brand & $\sigma_{0.2}, \mathrm{MPa}$ & $\sigma_{\theta}, \mathrm{MPa}$ & $\delta, \%$ \\
\hline 2024-T351 & 372 & 462 & 20.5 \\
\hline
\end{tabular}



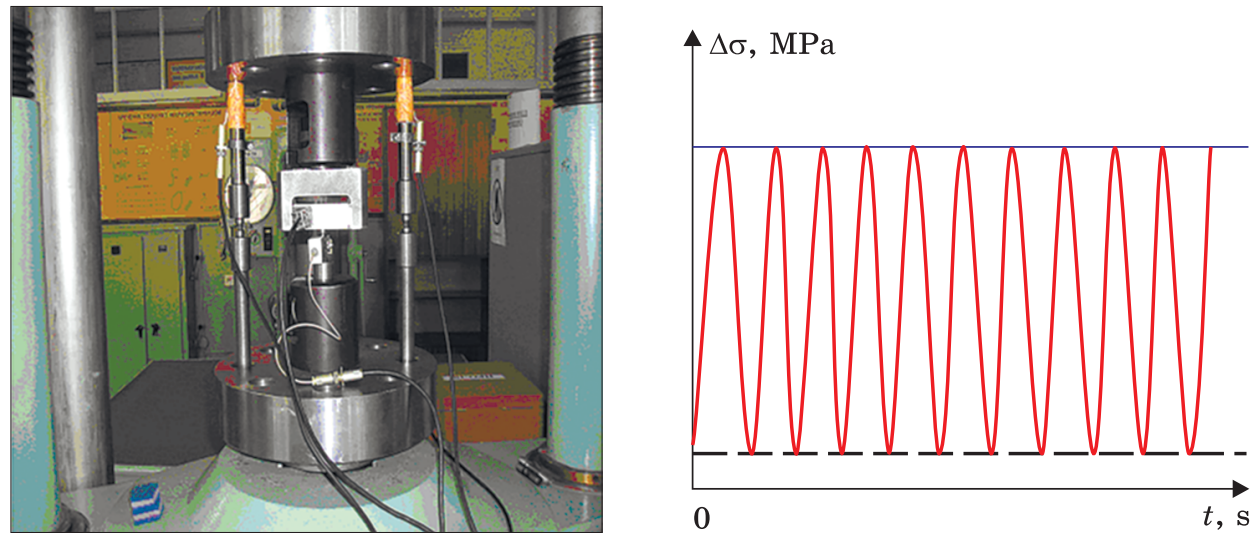

Fig. 1. View of the $\mathrm{ZD}-100 \mathrm{Pu}$ hydraulic machine with fragile samples and an installed video camera [26]

Fig. 2. The scheme of loading of samples [20]

$50 \mathrm{kN}$ at room temperature. Load mode is soft; cycle asymmetry coefficient $R=0.1$; load frequency $110 \mathrm{~Hz}$, the intensity of pulsed energy input into alloys was controlled by sudden increments of dynamic deformation $\varepsilon_{\text {imp }}$ according to SVL. The choice of $\varepsilon_{\text {imp }}$ as a parameter that characterizes the intensity of pulsed energy input into alloys, allows you to very easily assess its impact on fatigue life.

Studies of the effect of deformation strengthening of the surface layer on fatigue life were performed using ultrasonic impact treatment (UIT) $[15,16,27]$, which in recent years is often used to increase the fatigue life of heterogeneous aluminium alloys. In our opinion, the method of ultrasonic forging is one of the modern and useful methods of increasing fatigue life due to the surface strengthening of the nearsurface layers and the formation of compressive stresses in them. The authors [28] also observed the effect of ultrasonic impact treatment on fatigue strength, which in the alloy 2017-74 at a fatigue load of up to $10^{7}$ cycles increased by $4.16 \%$.

The disadvantage of using UIT can be related to some deterioration of the surface quality and the formation of wavy relief. To eliminate this disadvantage, which impairs the fatigue properties of the material, additional deformation can be applied, for example, rolling. However, UIT is also used to modify and align the corroded surface to restore the fatigue properties of aluminium alloys, for example, on surface corrosion [29]. The use of UIT to affect the fatigue life is carried out by using reinforced balls or shock elements that transmit the pulse of ultrasonic energy to a depth of $2 \mathrm{~mm}$.

In our work, the method of UIT described in $[15,16]$ was used to influence fatigue durability with the following experimental parameters: 
static load $\sim 25 \mathrm{MPa}$, a frequency of ultrasonic oscillations $-21 \mathrm{kHz}$, area of action $\sim 15 \mathrm{~mm}^{2}$, energy of one shock pulse $\sim 10-25 \mathrm{MPa}$, energy pulse duration $\sim 35 \mu \mathrm{s}$, total processing time per unit area was $\sim 5 \mathrm{~s} / \mathrm{mm}^{2}$.

We conducted a direct study of the structure on a transmission electron microscope JEM-200CX from JEOL (Japan), which allows us to get an idea of the structural-phase state of the material. Technical characteristics of the microscope: magnification $650000 \times$, resolution $0.3 \mathrm{~nm}$, accelerating voltage from 20 to $200 \mathrm{kV}$. Films for electron microscopic studies were prepared by electroerosive cutting followed by mechanical thinning, electrolytic polishing and final ionic thinning. The investigated area of the sample, which corresponded to the thickness of the film obtained after the first ionic thinning, was increased by the following ion etching procedures. Such procedures were used for each sample from 3 to 5 , which significantly increased the possibilities of statistical study of structural elements. The study was performed at an accelerating voltage of $200 \mathrm{kV}$. When considering films in an electron microscope at high magnifications, the type of microstructure changes significantly. Therefore, to decipher correctly the structure, it is necessary to begin research with small magnifications, gradually moving to larger ones.

\section{Experimental Results and Discussion}

\subsection{Deformation Hardening of Alloys Using SVL and UIT}

\subsubsection{Alloy 2024-T351}

Figure 3 shows the data on the fatigue life of the alloy 2024-T351 in the initial state according to the test results of three samples for each mode in the range of maximum values of the applied voltage 340-440 $\mathrm{MPa}$ at a load frequency of $110 \mathrm{~Hz}$.

Figure 3 shows that for samples of the alloy in the initial state at a load frequency of $110 \mathrm{~Hz}$ there is a similar relationship between the maximum cycle stress and fatigue life as at a frequency of $15 \mathrm{~Hz}$ (see Fig. 4) [20], which indicates a slight effect of load frequency on lowcycle fatigue alloy 2024-T351 in the initial state. As already noted, in order to quantify the impact of SVL on the fatigue life of the alloy, it is necessary to have a quantitative parameter of this assessment. For this parameter in all our researches, the size of an impulse of plastic deformation of an alloy (sample) $\varepsilon_{\text {imp }}$ in the course of realization of SVL is accepted. Examples of the dependence of the fatigue life of the alloy on the value of $\varepsilon_{\text {imp }}$ are shown in Fig. 5 and 6 for high values of maximum stress (400 and $440 \mathrm{MPa}$ ).

In Fig. 5 and 6 blue dots and dashed lines correspond to the samples destroyed under fatigue load with a frequency of $110 \mathrm{~Hz}$ in the initial state, and red dots - to the samples destroyed under fatigue load after 


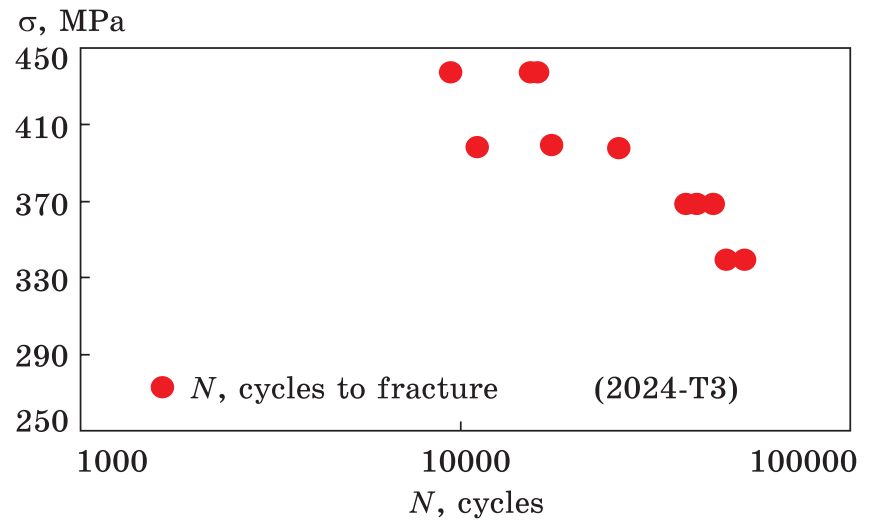

Fig. 3. The relationship between fatigue life and the maximum cycle stress for the alloy 2024-T351 in the initial state at a load frequency of $110 \mathrm{~Hz}$

Fig. 4. Dependence between fatigue life and maximum cycle stress for alloy 2024T351 in the initial state (fully painted dots - left line) and after pulse loading (SVL) (half-painted dots - right line) at a load frequency of $15 \mathrm{~Hz}$ [20]
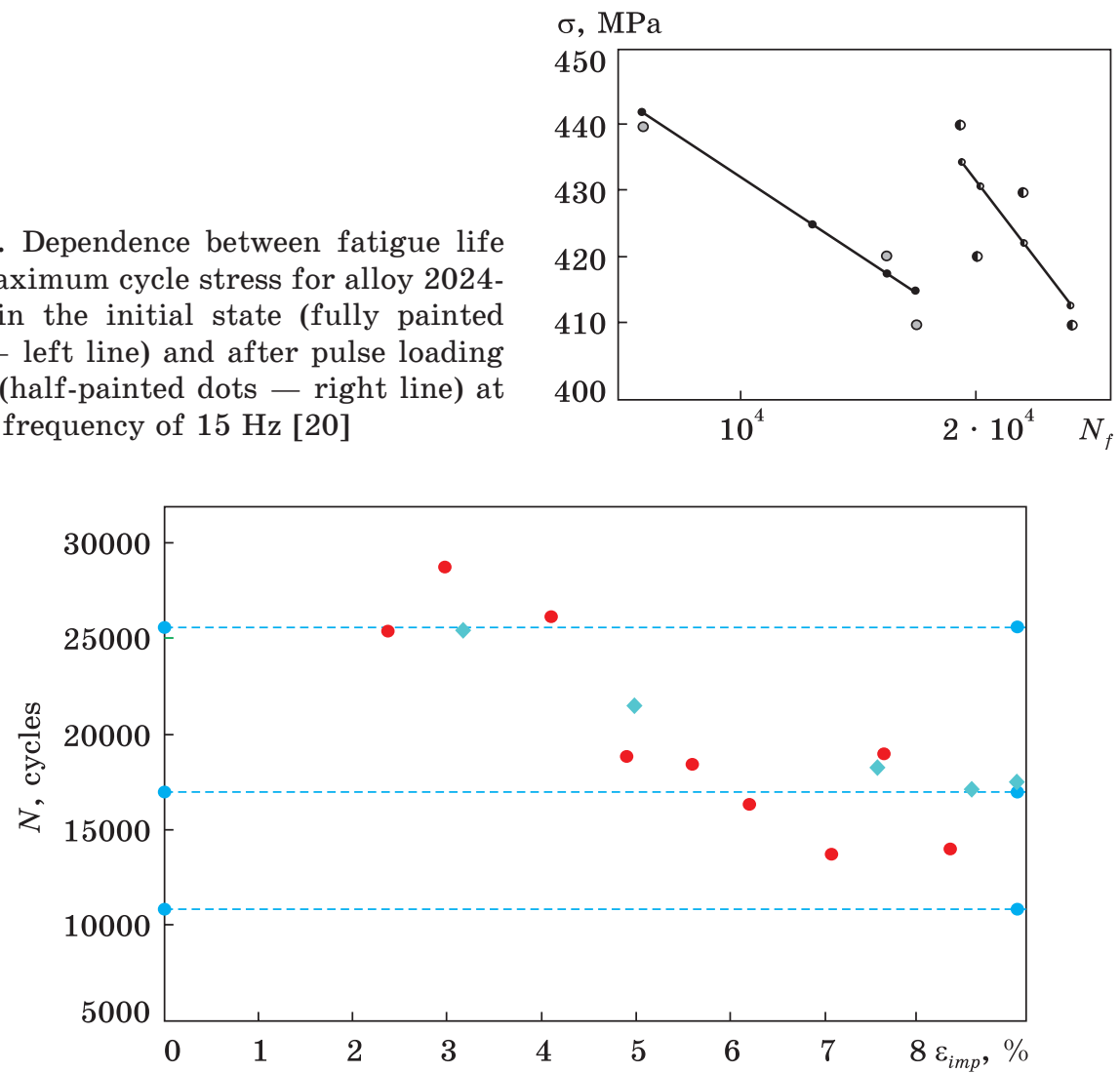

Fig. 5. Dependence of fatigue life of alloy 2024-T351 on the previous deformation $\varepsilon_{\text {imp }}$ during the implementation of SVL $\left(\sigma_{\max }=400 \mathrm{MPa}\right)$ at a load frequency of $110 \mathrm{~Hz}$ [24]

the implementation of SVL. We see that in comparison with the initial state the increased fatigue life after SVL is observed only at $\sigma_{\max }=$ $400 \mathrm{MPa}$ and deformation in the process of SVL 2.95\% (see Fig. 5). 


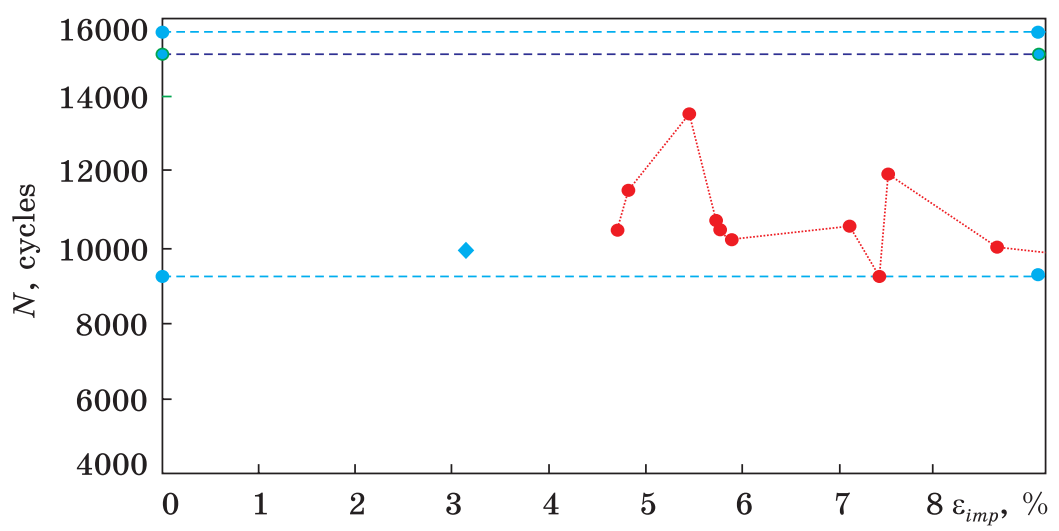

Fig. 6. The dependence of the fatigue life of the alloy 2024-T351 on the preliminary deformation $\varepsilon_{\mathrm{imp}}$ during the implementation of SVL $\left(\sigma_{\max }=440 \mathrm{MPa}\right)$ at a load frequency of $110 \mathrm{~Hz}$ [24]

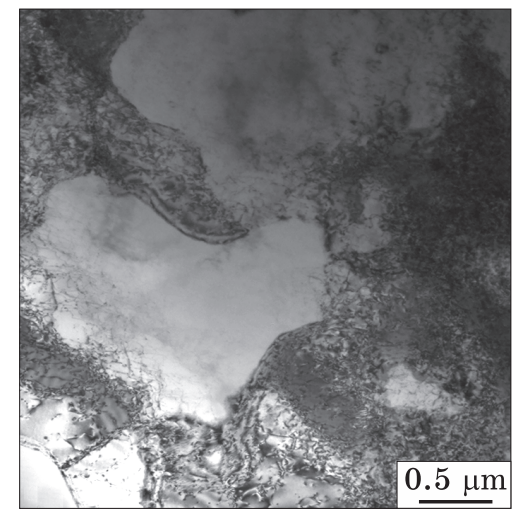

with deformation $\left.\varepsilon_{\text {imp }}=2.95 \%\right)-28767$ cycles. Statistical TEM analysis of the nanostructure of the samples after different modes of previous deformation intervention showed a significant difference in structure in these cases. For example, in foils investigated in the direction of stretching after fracture in the process of fatigue loading of samples in the initial state large areas of relaxation (recrystallized) structure are determined (Fig. 7), while after the previous SVL such radical changes of structure are not fixed. Delay of the relaxation changes in the structure after the application of prior SVL also is the main reason of increase of fatigue durability in this case.

Thus, the deformation in the process of SVL in the initial stages of its evolution can delay the development of the relaxation processes and, as experiments have shown, it leads to the preservation of the initial stages of synergistic structure only in a narrow range of the deformation extents induced by SVL. The probability of this process largely depends on the maximum cycle stress. For example, in the stress range 

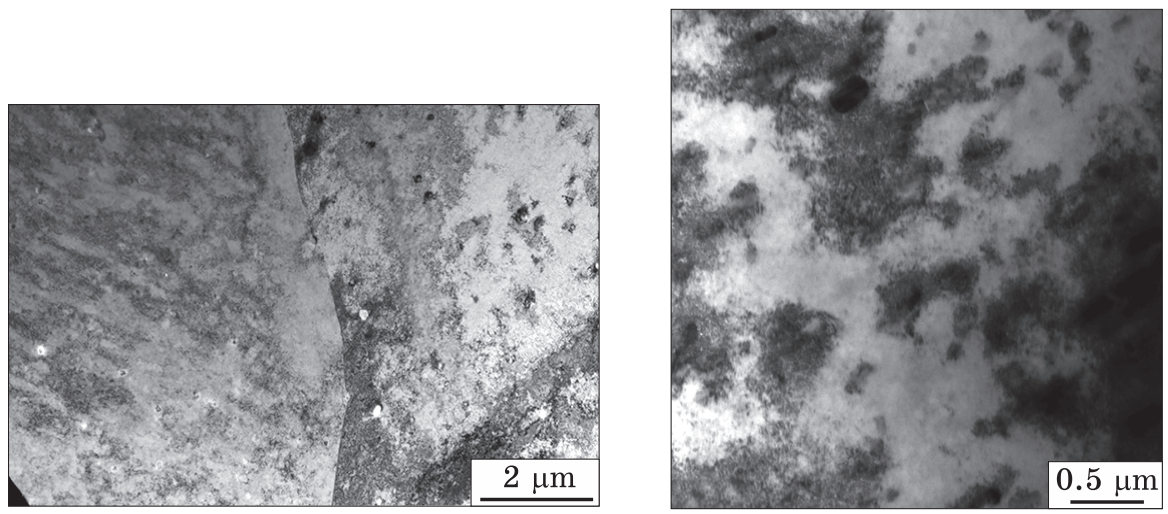

Fig. 8. An example of the TEM structure of a sample of alloy 2024-T351, destroyed under fatigue load with a frequency of $110 \mathrm{~Hz}$ after the previous SVL with a deformation of $\varepsilon_{\text {imp }}=2.95 \%\left(\sigma_{\max }=400 \mathrm{MPa}\right)$

Fig. 9. Example of TEM structure of a sample of alloy 2024-T351, destroyed under fatigue load with a frequency of $15 \mathrm{~Hz}$ after the previous SVL with deformation $\varepsilon_{\mathrm{imp}} \sim 5 \%\left(\sigma_{\max }=440 \mathrm{MPa}\right)+\mathrm{UIT}$

of 400-440 MPa, the most effective effect of the prior SVL on fatigue life should be expected at deformations of $2.5-5.5 \%$.

In our previous work [20], it was shown that the change in the phase composition of the alloy 2024-T351 is really observed at low temperatures and even without additional mechanical impact due to the possibility of dissolution and growth of reinforcing particles. The process becomes possible due to the liquid-like structure of the channels of hydrodynamic flow (HC) [19-23]. This structure of the channels is due to the increased concentration of vacancy defects, the self-organization of which under the action of a mechanical field leads to the formation of nuclei of channels of hydrodynamic flow (see below).

Returning to the analysis of the cause of the effect of SVL on the fatigue life of the alloy 2024-T3, we conducted a thorough analysis of the alloy microstructure by TEM after fracture under fatigue load of samples with the original microstructure (number of cycles before fracture 17004 cycles) and with the microstructure formed during the prior SVL with deformation $\varepsilon_{\text {imp }}=2.95 \%$ (number of cycles to failure 28767 cycles). In the experiment, we used the following:

The morphological difference of $\Theta-\mathrm{Al}_{2} \mathrm{Cu}$ and $\mathrm{S}-\mathrm{CuAl}{ }_{2} \mathrm{Mg}$ phases was taken into account: $\Theta$ - the phase had the form of a rectangle elongated in one direction, the width of which depended on the orientation relative to the plane of the foil; $\mathrm{S}$ - phase had the form of a sphere (or dot at lower magnification). The number of reflections of both phases on 100-300 fields of view was calculated, for which ion etching of each studied foil was used, which contributed to the increase in the number 

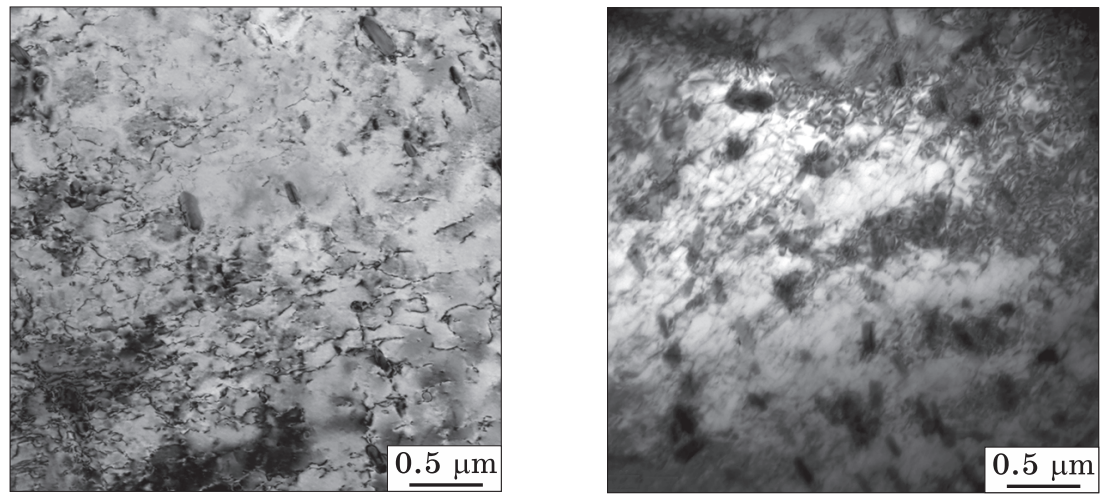

Fig. 10. TEM structure of the samples destroyed under fatigue load initial state

Fig. 11. TEM structure of the samples destroyed under fatigue load - after UIT

of fields of view. As a result of calculations, the following data were obtained (in the number of phase reflections on the area of $1 \mu^{2}$ ):

At fatigue destruction of the samples used in an initial condition, $\Theta-\mathrm{Al}_{2} \mathrm{Cu}-3.52, \mathrm{~S}-\mathrm{CuAl}{ }_{2} \mathrm{Mg}-1.82$. At fatigue destruction of the samples used after SVL with deformation of $2.95 \%, \Theta-\mathrm{Al}_{2} \mathrm{Cu}-2.57$, S$\mathrm{CuAl}_{2} \mathrm{Mg}-4.51$.

Thus, the prior SVL of the alloy sam7 and then contribute to the dissolution of particles of $\Theta$-phase and increase the number of particles of S-phase in fatigue tests, are destroyed (relax) during UIT and therefore do not cause the desired increase in fatigue life. Since separately applied UIT increases fatigue life (as described in the paragraph below), the negative effect of surface unevenness after UIT does not outweigh the positive from hardening, compressive stresses, etc.

Let us see now how a single UIT without prior deformation intervention (SVL) affects the fatigue life of the alloy 2024-T351. It should be accounted for that the fatigue life of the samples at each load mode has a significant discrepancy; so, researchers usually use the average statistical value of durability under the same test conditions for the results of 3 to 10 tests. However, given the high sensitivity of fatigue life to random deviations of surface quality or other parameters, we tried to move away from these methods of calculation and take into account only the maximum values of durability under selected conditions. In this case, at $\sigma_{\max }=425$ $\mathrm{MPa}$, the fatigue life of the alloy 2024-T3 51 at a frequency of $15 \mathrm{~Hz}$ can increase from 8882 cycles (the highest recorded fatigue life of the original alloy under selected conditions) to 12456 cycles after UIT.

Fig. 12. Dependencies of fatigue life on $\varepsilon_{\text {imp }}$ at: $(a) \sigma_{\max }=340 \mathrm{MPa} ;(b) 370 \mathrm{MPa}$; $(c)$ $400 \mathrm{MPa} ;(d) 440 \mathrm{MPa}$ [25] 

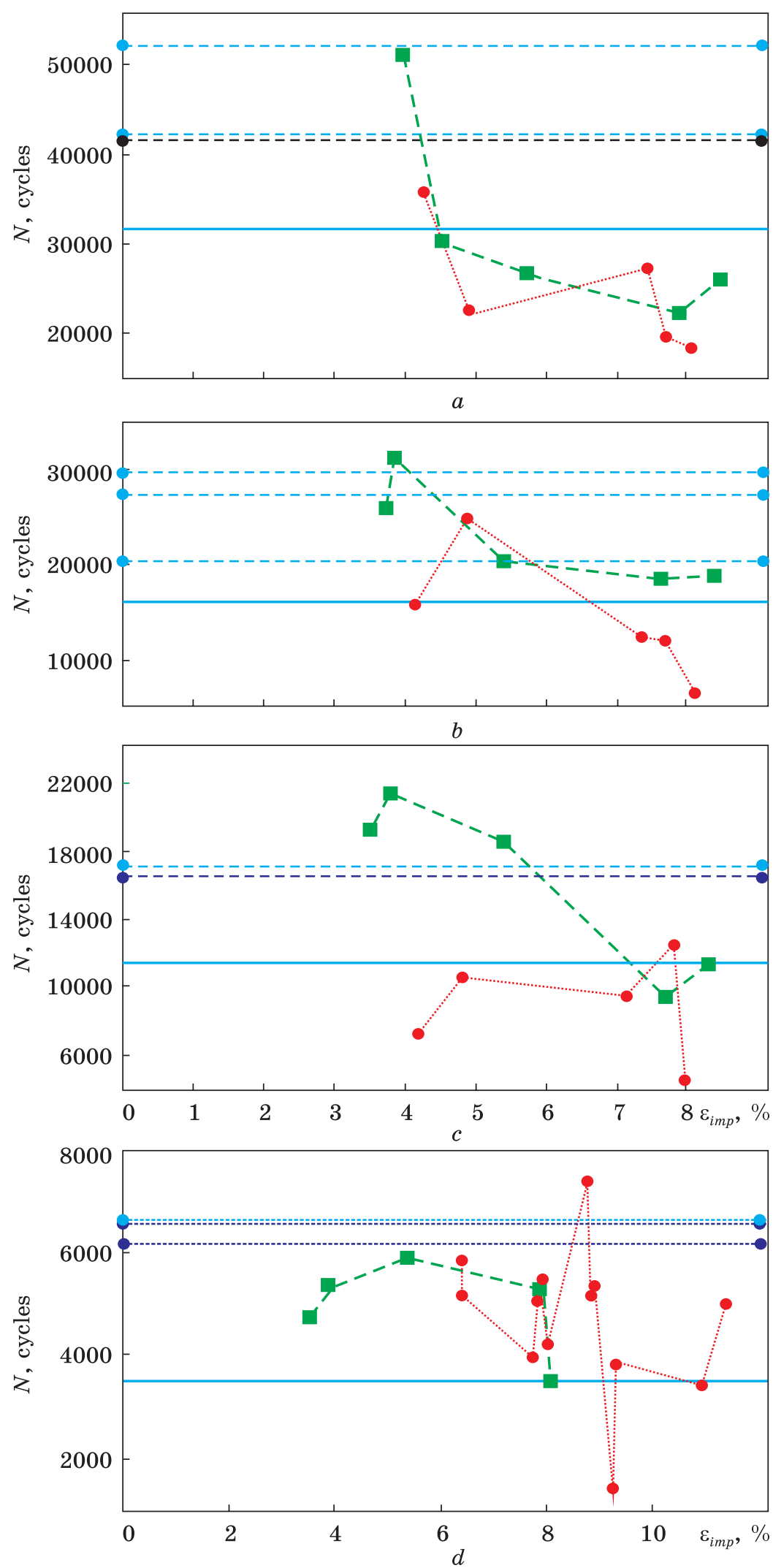
The difference in the TEM structure of the samples destroyed under fatigue load (Fig. 10 - initial state, Fig. 11 - after UIT) can be seen in Fig. 10 and 11.

We tried to estimate the volume fractions of the $\Theta$ and $S$ phases after a separate UIT in samples destroyed under fatigue load with a frequency of $15 \mathrm{~Hz}$ and a maximum cycle voltage of $410 \mathrm{MPa}$. We obtained the following values. At fatigue destruction of the samples used in an initial condition, $\Theta-\mathrm{Al}_{2} \mathrm{Cu}-1.38, \mathrm{~S}-\mathrm{CuAl} \mathrm{Al}_{2} \mathrm{Mg}-0.48$. At fatigue destruction of the samples processed by UIT, $\Theta-\mathrm{Al}_{2} \mathrm{Cu}-1.38, \mathrm{~S}_{-} \mathrm{CuAl}_{2} \mathrm{Mg}-0.50$.

It was interesting to compare the phase composition of the alloy 2024-T3 51 not only after fatigue failure, but also before, in the initial state and after UIT. Initial state: $\Theta-\mathrm{Al}_{2} \mathrm{Cu}-1.55 ; \mathrm{S}-\mathrm{CuAl}{ }_{2} \mathrm{Mg}-0.54$. After UIT: $\Theta-\mathrm{Al}_{2} \mathrm{Cu}-1.76$; $\mathrm{S}-\mathrm{CuAl}{ }_{2} \mathrm{Mg}-0.68$.

We see that after fatigue loading and destruction the concentration of both phases decreases significantly, and after UIT in comparison with the initial state increases. The reasons for changes in the phase composition of the alloy in the used processing modes require additional research.

\subsubsection{Alloy D16CzATW}

All studies on the pulsed input of power energy into the aluminium alloy D16CzAT as well as the alloy 2024-T351 were conducted on an upgraded test machine $\mathrm{ZD} 100 \mathrm{Pu}$. Estimates of fatigue life were performed on a resonant test machine RUMUL TESTRONIC $50 \mathrm{kN}$ and a machine 'Instron-8802' at the same load modes at room temperature. The test modes of the D16CzATW alloy specimens after pulsed energy injection to assess their fatigue life were similar to the initial specimen test specimens: soft and hard load modes; cycle asymmetry coefficient $R=$ $=0.1$; the approximate load frequency is of $110 \mathrm{~Hz}$, and the fixed load frequency is of $15 \mathrm{~Hz}$. As in previous works, the intensity of pulsed energy input into the alloy was controlled by sudden increases in the dynamic deformation $\varepsilon_{\text {imp }}$.

The modes of pulsed energy input into the alloy by the parameter $\varepsilon_{\text {imp }}$ in this work were as follows $\varepsilon_{\text {imp }}=3.5-8.5 \%$. Samples of sheet industrial aluminium alloy D16CzATW with a thickness of $3 \mathrm{~mm}$ were tested. The value of $\varepsilon_{\text {imp }}$ during pulse deformation was controlled by the optical method. The base for measuring deformations during static tension with a standard extensometer was $16 \mathrm{~mm}$. Structural changes in the alloy during the experiments were investigated, as in the alloy 2024T351, by statistical methods of TEM.

The mechanical properties of alloy D16CzATW as well as alloy 2024T3 depend on the concentration of reinforcing phases $\Theta$ and S. In our works, the concentration of particles of both phases for all studied processing modes was estimated by the average results of direct meas- 

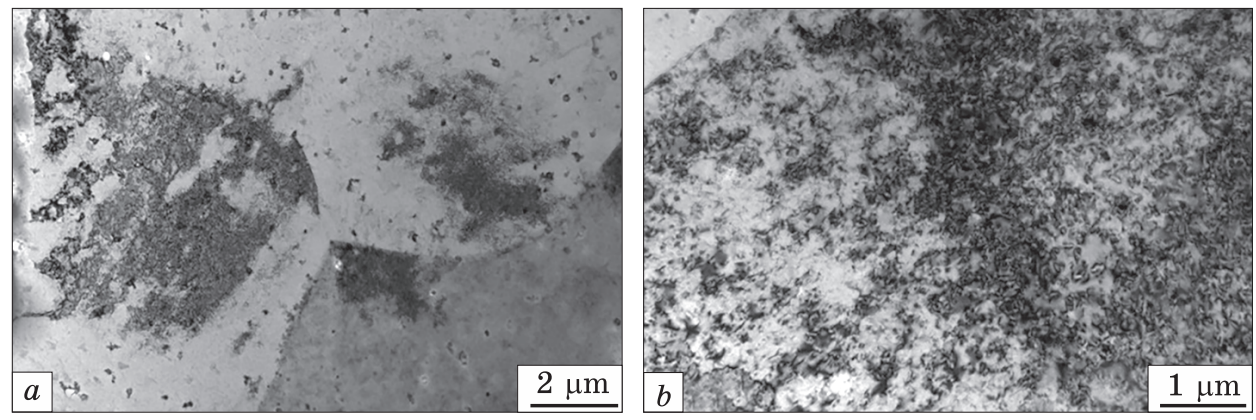

Fig. 13. Examples of TEM-structure destroyed at loading samples after SVL with 7-month exposure $(a)$ and without exposure $(b)$

urements of the number of particles per real area of the sample. The statistics of this method were very high: for each mode of mechanical examination used from 3 to 5 samples, on each sample from the working area cut at least 3 samples for TEM-study, each sample of foil was repolished at least 5 times. It has been experimentally proven that increasing the load frequency from $15 \mathrm{~Hz}$ to $110 \mathrm{~Hz}$ and switching from hard load mode, Instron-8802 test to soft mode, RUMUL TESTRONIC $50 \mathrm{kN}$ test, and leads to a slight reduction in the number of cycles before failure alloy.

The dependences of the fatigue life of the D16CzATW alloy on the value of $\varepsilon_{\text {imp }}$ without exposure and after exposure for 6-7 months were obtained in our work. for all modes of variable loading are given in Fig. 12. Here, at $\varepsilon_{\text {imp }}=0$, the data of tests on fatigue on three samples of an alloy in an initial condition (blue points and dashed lines), red points on all graphs correspond to the fatigue durability of an alloy after SVL of various intensity without endurance, green squares and lines - after SVL and endurance. All graphs show the dependences of fatigue life on $\varepsilon_{\text {imp }}$ at different values of the maximum cycle stress: 340 , 370,400 , and $440 \mathrm{MPa}$.

Let us consider the above results. At $\sigma_{\max }=340 \mathrm{MPa}$, the fatigue life of samples with exposure is greater than without exposure, but still less than in the initial state. At $\sigma_{\max }=370 \mathrm{MPa}$, the fatigue life of samples with endurance is greater than that of samples in the initial state, but unfortunately there are no analogues at one deformation in the process of SVL samples with and without endurance. At $\sigma_{\max }=400 \mathrm{MPa}$ in the deformation range of $3-4 \%$, the durability of samples with exposure is greater not only for the durability of samples without exposure, but also for the durability of samples in the initial state. At $\sigma_{\max }=440 \mathrm{MPa}$, the exposure effect is absent. Thus, endurance after SVL in a narrow interval of deformation can increase fatigue durability, in our opinion, thanks to slowing down of relaxation processes. TEM observations 
showed that in the samples destroyed under fatigue load after SVL and exposure for 7 months, no significant development of recrystallization was detected (Fig. 13, a), in contrast to the samples without exposure (Fig. 13, b).

The microstructures shown in Fig. 13, $b$ are characterized by the presence of large planes of 'white' contrast, which is a consequence of a perfect (recrystallized) structure. This structure is less susceptible to etching during the electrochemical preparation of the foil for the TEM study, and the areas with such a structure remain thicker, through which the electron beam does not pass during the transmission study. During aging, the number of the recrystallization centres decreases, probably due to a decrease in the concentration of particles of the reinforcing phases, as shown by our statistical studies of TEM structure, and the development of recrystallization processes does not cause in these cases the formation of large areas of perfect recrystallized structure in Fig. 13, $b$. The total decrease in the concentration of particles of the reinforcing phases during long-term exposure is not a necessary condition for increasing the fatigue life of the alloy, because the roles in the formation of recrystallization centres of particles $\Theta$ and $S$ phases are different. The particles of the $\Theta$-phase have the shape of an asymmetric geometric figure of the type of a rectangular parallelepiped with a complex stress field around each particle. At the same time, the particles of the S-phase have the shape of a sphere, and the stress field formed by these particles is much smaller than the field around the particles of the $\Theta$-phase. Therefore, a decrease in the concentration of recrystallization centres will result only in a decrease in the concentration of $\Theta$-phase particles, even with an increase in the concentration of Sphase particles, which in most cases is observed.

Our studies quantitative assessment of the concentration of particles in the initial samples and after SVL exposure with endurance and destruction under fatigue load is significantly reduced (in the number of particles per $1 \mu^{2}$ of the real working area of the sample): initial state $-0.46 \Theta$-phase and $0.39 \mathrm{~S}$-phase; after treatment $-0.27 \Theta$-phase and $0.17 \mathrm{~S}$-phase. We see that the treatment of SVL with exposure leads to a decrease in the concentration of particles $\Theta$-phase almost 2 times. It is shown that long-term exposure of alloy samples for 6-7 months after shock-vibration load has a positive effect on increasing the fatigue life of the alloy. The optimal mode of SVL-processing and application of exposure for $6-7$ months $\left(\varepsilon_{\text {imp }}=3.5-4 \%\right)$ was revealed. For example, at $\sigma_{\max }=340 \mathrm{MPa}$, the fatigue life of the alloy after the above processing modes increases compared to the average values of fatigue life of the alloy in the initial state by $11.6 \%$, at a stress of $\sigma_{\max }=370 \mathrm{MPa}-$ by $18.4 \%$, at a stress of $\sigma_{\max }=400 \mathrm{MPa}-$ by $21.2 \%$. 


\subsection{A Survey of Concept of the Mechanism of Formation and Development of Fatigue Cracks}

In most of the literature on the influence of various factors on fatigue life, it is believed that durability depends largely on the topography of the sample or part surface. Some authors propose to improve the surface quality by additional rolling or polishing (see, for example, [29]). However, many experimental works have shown that the fatigue cracks are usually initiated in the near-surface region, at a distance of 10-20 $\mu \mathrm{m}$ from the surface, and do not appear on the surface itself. This factor is very important because it sheds light on the mechanism of crack nucleation - microcracks.

However, the work of many other researchers has shown that untreated (polished) samples are still destroyed primarily from the surface. Moreover, the displacement of the crack initiation cited deeper beneath the sample surface, which is deformed, is mainly caused by the compressive stresses in the surface layer. Some authors even find a correlation between the maximum residual tensile stresses and the depth of crack initiation [18]. The situations that are most frequently experienced by of Al-based alloys for the aviation industry are analysed. Since products made of them are subjected to non-stationary fatigue loads throughout their operation. Pure aluminium is a very light and highductile metal; therefore, all technologies in the aviation industry are associated with increasing its strength while maintaining ductility.

A model of the behaviour of a crystalline material in a mechanical field was proposed and explained in our previous works [19-23]. Deformation is a way of relaxation of an external energy field should be born in mind. During the initial stages, deformation is elastic. It is subject to a linear law and fit to the classical theory of dislocations. Then, the linear law violates over time due to the interaction between dislocations, since the obstacles are formed for the movement of dislocations even in single crystals, as a result, the deformation becomes plastic (irreversible). This process occurs during the early stages of loading in the heterogeneous, multiphase metal alloys. Since the movement of dislocations can no longer provide macroscopic deformation (plastic deformation), despite the fact that dislocations are present in the material.

Then, self-organization of the structure of the material in the form of structural elements becomes possible, since, according to the laws of synergetic, that in systems that are far from equilibrium, the laws of linear thermodynamics do not apply. These structural elements are able to continue plastic deformation without dislocations, due to mass transfer through channels with a liquid-like structure, complete with vacancy defects. We have considered a theoretical model of the location of areas enriched with vacancies in the near-surface layers of the material 
in a mechanical field; it allows substantiating the formation of fatigue microcracks in these areas. Let us consider this model in more detail, since it explains the development of fatigue fracture in metallic materials, and it is repeatedly confirmed by experimental data.

Previously it was believed that, if the generation of vacancies occurs at the steps of dislocations, then the ultrasonic vibrations (and/or periodic loads) would contribute to increase the concentration of nonequilibrium vacancies in an investigated material. It is possible that a similar case may occur at ultrasonic impact treatment, but we, unfortunately, have not investigated it.

The laws of nonequilibrium and nonlinear thermodynamics are set as principle of understanding of the behaviour of crystalline materials in a mechanical field while system is far from thermodynamic equilibrium. These laws have been considered in detail in the world-famous monographs [30-33]. The main thing in these laws is that in a system that is far from equilibrium and under the influence of a significant energy field, the trajectory of the kinetic behaviour of a thermodynamic system can change. Processes of the self-organization of structure may take place in this system; this is due to a decrease the entropy. Examples of this pattern of behaviour have been given in ordinary life, and not only in various scientific fields.

Since the 1970s, scientists in various scientific disciplines have published a large number of studies of the processes of self-organization of various systems. They were considered as the processes of self-organization of the system as a whole, and the self-organization of individual elements of the system. In the first case, this explains the appearance of elements of a dissipative structure, such as channels of hydrodynamic flow, and changes in the deformation mechanism during the plastic deformation. In the second case, it leads to an understanding of the self-organization of the structure through the formation of vacancy defects as the main sources of the liquid-like structure of the hydrodynamic flow channels and the threat of the formation of nuclei of fatigue cracks. The latter is related to the study of the location of places of selforganized matter, which is why our calculations and the calculations of other authors [34-37].

Similarly to [35], we write the equation for the distribution of the vacancy density in a three-dimensional sample in the form of a rectangular parallelepiped in the stationary case,

$$
\left(K-n\left(\mathbf{r}_{2}\right) / \tau\right) / D_{v}+\operatorname{div}\left(\operatorname{grand} n\left(\mathbf{r}_{2}\right)+\operatorname{grand} S n\left(\mathbf{r}_{2}\right)\right)=0 .
$$

All designations are the same as in [35], except

$$
\begin{gathered}
r_{2}=i x+j y+k z, \\
S=\int_{\Omega} E\left(r_{2}-r_{1}\right) n\left(r_{1}\right) d r_{1},
\end{gathered}
$$


$E\left(r_{2}-r_{1}\right)$ is the energy of pair interaction of vacancies. We assume that $E$ is of the form

$$
E(R)=-d_{1} / R^{3}-a_{1} / R^{4}+b_{1} / R^{8} ;
$$

here, $R$ is the distance between two interacting vacancies:

$$
\begin{gathered}
R=\sqrt{\left(x-x_{1}\right)^{2}+\left(y-y_{1}\right)^{2}+\left(z-z_{1}\right)^{2}}, \\
a_{1}=A / k_{B} T, b_{1}=B / k_{B} T, d_{1}=D / k_{B} T,
\end{gathered}
$$

$A, B$ and $D$ are positive constants. We are looking for solution $n\left(r_{2}\right)$ in the form of a series

$$
\begin{gathered}
n=C+h f\left(\mathbf{r}_{2}\right)+\mathrm{O}\left(h_{2}\right), \\
|h| \ll 1,
\end{gathered}
$$

We consider the diffusion coefficient $D_{V}$ to be sufficiently small, so that from Eq. (1),

$$
C \approx K \tau \text {. }
$$

We are looking for the conditions under which $f$ is an ordered oscillatory function, equate coefficients of $h$. Similarly looking for

$$
x-x_{1}=r \sin \theta \cos \phi, y-y_{1}=r \sin \theta \sin \phi, z-z_{1}=r \cos \theta .
$$

Then from (4)

Assume it is true for all

$$
R=|r|
$$

$$
r>0 .
$$

It is also assumed that vacancies cannot approach each other at a distance less than $\zeta$, and $n\left(r_{1}\right)=$ const. Then, using (2), we have:

$$
S \propto \int_{\Omega} E\left(r_{2}-r_{1}\right) d r_{1}=\int_{\xi}^{\infty} E(1 / r) d r
$$

$E(1 / r)=E(1 / R)$ is determined from Eq. (3). As seen, for large $r$, $E(1 / r) \rightarrow 0$. We choose a sufficiently large positive $\rho$ such that:

$$
S \approx \int_{\xi}^{\rho} E(1 / r) d r
$$

One can that $S$ is approximately the same $r_{2}$ for each one sufficiently distant from the sample surface. Thus

$$
\operatorname{grad} S=0,
$$

and, as we see from Eq. (1), taking into account Eq. (6), there can be no ordering of $f$, except that $f=$ const. Self-organization of vacancies can occur only at a distance $r_{2}$ close to the sample surface; therefore, a sphere of radius $\rho$ simply will not fit there, but there will be a truncated sphere. 
We consider $r_{2}$ closer to the sample surface, so that a sphere with radius $\rho$ is only slightly truncated. Then, $S$ can be expanded in a Maclaurin series in $x, y$, and $z$ so that:

$$
\begin{gathered}
\operatorname{divgrad} S=a_{0}+a x^{2}+b y^{2}+c z^{2}+\ldots, \\
|a|,|b|,|c|<<\left|a_{0}\right|,
\end{gathered}
$$

As we can see from (3), $a_{1}, b_{1}, d_{1}$, it is always possible to choose in such a way that the condition is fulfilled:

$$
a_{0}>0 \text {, }
$$

and we will have ordered oscillating solutions for $f$.

We can see that the overall arrangement of ordered states throughout the thickness of the sample can only exist for a very thin sample.

Self-organization of vacancies can occur only if the vacancies are at a sufficiently small distance from the sample surface. More specific meanings can be named only by knowing $a_{1}, b_{1}, d_{1}$; see Eq. (3).

Thus, if vacancies are an integral part of a fatigue microcrack, therefore, its development, and the subsequent destruction of the object as a whole, always starts from the near-surface layer. This suggests that an increase in fatigue life should apply the method of exposure, which will change the mechanical properties of the surface layer of the object.

\section{Conclusions}

This article is devoted to retrieval of economically and experimentally accessible method of deformation effect on fatigue life of aviation aluminium alloys, which are in use under the constant action of the timedependent mechanical field. The brief review of the last years works revealed strain hardening to hasten the relaxation processes. These processes decrease the fatigue life. Authors of this article revealed by the example of deformation behaviour of alloys 2024-T351 and D16ChATW, fatigue life of heterogeneous alloys to increase under such conditions:

- Plastic deformation of crystalline material take place in conditions remote from thermodynamic equilibrium when laws of nonlinear physics act and dislocation deformation do not act. In such conditions, the mechanism of plastic deformation changes from dislocation slide to hydrodynamic plastic flow by channels (HC) with amorphous (liquidlike) structure inside them. Formation of HC presents the consequence of synergetic self-organization of material. Formation liquid-like structure inside $\mathrm{HC}$ is determined the vacancy defects localization in sites close to surface; this result is corroborated by analytic calculation and by many experiments. Liquid-like structure of $\mathrm{HC}$ stimulates the change of phase composition by speeding-up of particles $\Theta-\mathrm{Al}_{2} \mathrm{Cu}$ and $\mathrm{S}-\mathrm{CuAl}_{2} \mathrm{Mg}$ resolution and formation. Change of phase composition has an influence 
on fatigue life, mainly, due to dilution $\Theta$-particles. These particles have intricate geometrical form, which localizes the deformation influence and accelerates the relaxation processes. Calculations of $\Theta$-particles composition were implemented by TEM method contain in article.

- The possibility to influence on fatigue life of aluminium alloys by dynamic deformation with pulse loading (SVL) was examined in this article. As a numerical parameter authors proposed to use the magnitude of plastic deformation $\varepsilon_{\text {imp }}$ induced by SVL. It was revealed that, at $\sigma_{\max }=400 \mathrm{MPa}$, one may expect for the longest fatigue life at $\varepsilon_{\mathrm{imp}}=2-4 \%$, and at $\sigma_{\max }=440 \mathrm{MPa}$, at $\varepsilon_{\mathrm{imp}}=3-5 \%$. It was established that the fatigue life increase observed after prior SVL is related to the change in phase composition: thus, at $\sigma_{\max }=400 \mathrm{MPa}$ and $\varepsilon_{\operatorname{imp}}=2.95 \%$ the SVL promotes the decrease of the $\Theta$-particles content and the increase of the S-particles content in the surface layers of alloy.

- It was achieved prolonged quotation of specimens (6-7 of month after SVL) to promote to increase of fatigue life of specimens. It was discovered the optimal procedure of SVL and quotation. It was established this SVL with quotation procedure decreases the $\Theta$-particles content.

- The article contains quantitative results of the effects of ultrasonic impact treatment (UIT) of the surface layer applied after SVL (SVL + UIT) - (the first case - complex treatment) and a single UIT process (the second case) on fatigue life. In the first case, the effect was negative - fatigue life did not increase. TEM investigation registered the concentration of $\Theta$-particles in initial state but the considerably recrystallized microstructure was also observed. The following conclusion was made: the complex treatment before fatigue test only promotes the enhanced development of relaxation processes but no positive influence on fatigue life occurs. However, single UIT processing of the surface layer (the second case) leads to the increase in fatigue life and to the decrease in the $\Theta$-particles content.

Therefore, the main conclusion of our review consists in the following: fatigue life of aviation aluminium alloys can be appreciably increased by using only one method deformation influence (UIT is rather desirable). Deformation treatment owes be of the same type (but not complex) as long as the complex treatment may induce the new type of microstructure self-organization and hasten the relaxation processes.

Acknowledgments. We express our gratitude to Corresponding Member of the N.A.S. of Ukraine, Prof. Valentyn A. Tatarenko for active participation in the discussion of self-organization of vacancy defects in plastic deformation of metal crystals. The same way we express our gratitude to Senior Staff Research Scientist of Laboratory of mechanical tests and metallographic investigations of G.S. Pisarenko Insti- 
tute for Problems of Strength of the N.A.S. of Ukraine, Doctor of Science (technical/engineering sciences) Andriy A. Kotliarenko for carrying out of fatigue life testing on machine INSTRON 8802, 19215.

\section{REFERENCES}

1. C. Froustey, J.L. Lataillade, Int. J. Fatigue, 30, No. 5: 908 (2008); https://doi.org/10.1016/j.ijfatigue.2007.06.011

2. P. Ohnistova, M. Pisko, M. Petrenec, J. Dluhos, J. Hornikova, P. Sanders, Materials, 12, No. 21: 3605 (2019); https://doi.org/10.3390/ma12213605

3. M.S. Rana, T. Yamanaka, C. Makabe, J. Solid Mech. Mater. Eng., 3, No. 7: 968 (2009); https://doi.org/10.1299/jmmp.3.968

4. Md.Sh. Ferdous, C. Makabe, M.S. Rana, T. Miyazaki, Eng. Fail. Anal., 18, No. 1: 968 (2011);

https://doi.org/10.1016/j.engfailanal.2010.08.007

5. E. Chabouk, M. Shariati, M. Kadkhodayan, J. Mater. Eng. Perform., 30, No. 4: 2864 (2021);

https://doi.org/10.1007/s11665-021-05613-7

6. P. Xia, Z. Liu, S. Bai, J. Mater. Eng. Perform. 30: 2669 (2021)

https://doi.org/10.1007/s11665-021-05626-2

7. T. Soiichiro, S. Moe, F. Riccardo, MATEC Web of Conferences, 165,14012 (2018); https://doi.org/10.1051/matecconf/201816514012

8. E. Janteccchia, A.M.S. Hamonda, F. Masharavati, E. Zalnechad, M. Cabibbo, M. El Mehtedi and S. Spigarelli, Adv. Mater. Sci. Eng., 2016: 9573524; https://doi.org/10.1155/2016/9573524

9. Q. Zhang, Y. Zhu, X. Gao, Y. Wu, C. Hutchinson, Nat. Commun., 11: 19071 (2020); https://doi.org/10.1038/s41467-020-19071-7

10. N.R. Gates, A. Fatemi, Procedia Eng., 101:159 (2015); https://doi.org/10.1016/j.proeng.2015.02.021

11. W.P. Mason, Journ. Acoust. Soc. Am., 28, No. 6: 1207; https://doi.org/10.1121/1.1908595

12. E. Willertz, Int. Met. Rev., 25, No. 1:65 (1980); https://doi.org/10.1179/imtr.1980.25.1.65

13. G. Schoeck, Int. J. Mater. Res., 73, No. 9: 576 (1982); https://doi.org/10.1515/ijmr-1982-730907

14. H. Mayer, Int. J. Fatigue, 28, No. 11: 1446 (2006); https://doi.org/10.1016/j.ijfatigue.2005.05.020

15. B. Mordyuk, G. Prokopenko, J. Sound Vib, 308, No. 3: 855 (2007); https://doi.org/10.1016/j.jsv.2007.03.054

16. B. Mordyuk, G. Prokopenko, Y. Milman, M. Iefimov, A. Sameljuk, Mater. Sci. Eng. A., 563: 138, (2013). https://doi.org/10.1016/j.msea.2012.11.061

17. A. Berg-Pollack, F.-J. Voellmecke, C.M. Sonsino, Int. J. Fatigue, 33, No. 4: 513 (2011); https://doi.org/10.1016/j.ijfatigue.2010.09.017

18. L. Wagner, Mater. Sci. Eng. A, 263, No. 2: 210 (1999) https://doi.org/10.1016/S0921-5093(98)01168-X

19. E. Zasimchuk, L. Markashova, A. Baskova, T. Turchak, N. Chausov, V. Hutsaylyuk, V. Berezin, J. Mater. Eng. Perform., 22: 3421 (2013); https://doi.org/10.1007/s11665-013-0630-z. 
20. E. Zasimchuk, T. Turchak, A. Baskova, N. Chausov, V. Hutsaylyuk, J. Mater. Eng. Perform., 26, No.3: 1293 (2017); https://doi.org/10.1007/s11665-017-2564-3.

21. E. Zasimchuk, O. Baskova, O. Gatsenko, T. Turchak, J. Mater. Eng. Perform., 27, No. 8: 4183 (2018); https://doi.org/10.1007/s11665-018-3515-3

22. E.E. Zasimchuk, V.I. Zasimchuk, T.V. Turchak, Usp. Fiz. Met., 14, No. 3: 275 (2013); https://doi.org/10.15407/ufm.14.03.275 (in Russian).

23. E. Zasimchuk, T. Turchak , N. Chausov, Results in Materials , 6: 100090 (2020); https://doi.org/10.1016/j.rinma.2020.100090

24. M. Chausov, E. Zasimchuk, P. Maruschak, O. Khyzhum, A. Pylypenko, O. Prentkovskis, J. Brezinova, Iran. J. Sci. Technol. Trans. Mech. Eng. (2021); https://doi.org/10.1007/s40997-021-00443-3

25. M. Chausov, J. Brezinova, E. Zasimchuk, P. Maruschak, O. Khyzhum, A. Pylypenko, P. Bazarnik, J. Brezina, J. Mater. Eng. Perform., 30: 6235 (2021); https://doi.org/10.1007/s11665-021-05868-0

26. M.G. Chausov, V.B. Berezin, A.P. Pylypenko, V.B. Hutsaylyuk, J. Strain Analysis Eng. Design, 50, No. 1: 61 (2015); https://doi.org/10.1177/0309324714548085

27. S.S. Hassan, M.N. Hamzah, R.M. Abed, Q. J. Eng. Sci., 10, No. 2: 171,(2017); https://qu.edu.iq/journaleng/index.php/JQES/article/view/198

28. Hussain J. M. Alalkawi, Aseel A. Alhamdany, Marib R. Abdul Hassan, Al-Nahrain J. Engineering Sciences, 21, No. 1: 141 (2018); http://doi.org/10.29194/NJES21010141

29. X. Ye, Y. Zhu, D. Zhang, Adv. Mater. Res., 189-193: 897 (2011); https://doi.org/10.4028/www.scientific.net/AMR.189-193.897

30. G. Nicolis and I. Prigogine, Self-Organization in Nonequilibrium Systems (Wiley-Interscience: New York: 1977).

31. P. Glansdorff and I. Prigogine, Thermodynamic Theory of Structure, Stability and Fluctuations (Wiley: New York: 1971).

32. H. Haken, Synergetics (Springer-Verlag Berlin Heidelberg: 1983); https://doi.org/10.1007/978-3-662-10184-1

33. V. Ebeling, The Formation of Structures in Irreversible Processes (Mir: Moscow: 1979) (in Russian).

34. V. Harchenko, I. Lisenko, A. Schokotova, A. Bashtova, D. Harchenko, E. Ovcharenko, S. Kohan, X. Wu, B. Wen, L. Wu, W. Zhang, Prog. Phys. Met, 18, No. 4: 295 (2017); https://doi.org/10.15407/ufm.18.04.295

35. O. Oliinyk, V. Tatarenko, Dopov. Nac. Akad. Nauk Ukr., 3: 55 (2019); https://doi.org/10.15407/dopovidi2019.03.055

36. T.M. Radchenko, O.S. Gatsenko, V.V. Lizunov, V.A. Tatarenko, Prog. Phys. Met., 21, No. 4: 580 (2020); https://doi.org/10.15407/ufm.21.04.580

37. T.M. Radchenko, V.A. Tatarenko, H. Zapolsky, D. Blavette, J. Alloys and Compounds, 452, No. 1: 122 (2008); https://doi.org/10.1016/j.jallcom.2006.12.149

Received 20.07.2021; in final version, 08.11.2021 
O.Е. Засимчук ${ }^{1}$, М.Г. Чаусов ${ }^{2}$, Б.М. Мордюк ${ }^{1}$, O.I. Баскова ${ }^{1}$, В.I. Засимчук ${ }^{1}$, T.В. Турчак ${ }^{1}$, О.С. Гаценко ${ }^{1}$

${ }^{1}$ Інститут металофізики ім. Г.В. Курдюмова НАН України, бульв. Академіка Вернадського, 36, 03142 Київ, Україна

${ }^{2}$ Національний університет біоресурсів і природокористування України, вул. Героїв Оборони, 15, 03041 Київ, Україна

\section{ОСОБЛИВОСТІ ДЕФОРМАЦІЙНОГО ЗМІЦНЕННЯ ГЕТЕРОГЕННИХ СТОПІВ АЛЮМІНІЮ ЗАДЛЯ ПІДВИЩЕННЯ ВТОМНОЇ ДОВГОВІЧНОСТИ}

Гетерогенні стопи алюмінію мають попит в авіаційній галузі, де важливою є спроможність матеріалу протистояти втомним навантаженням. Темою статті є пошук найбільш експериментально доступних методів деформаційного впливу на такі матеріали з метою збільшення втомної довговічности. На жаль, попередні дослідження мали неоднозначний характер через велику кількість чинників впливу на втому металевих матеріалів при однотиповому механічному навантаженні; тому ми обрали динамічне навантаження з імпульсним підвантаженням. Виявилося, що для гетерогенних стопів 2024-T351 і D16CzAT імпульсне підвантаження (ударно-коливне навантаження - УКН) в процесі статичної деформації сприяє збільшенню подальшої втомної довговічности за певної величини деформації в процесі дії імпульсу. Наприклад, для стопу 2024-Т351 при максимальній напрузі змінного навантаження $\sigma_{\max }=400$ МПа найбільшу втомну довговічність слід чекати за деформацій $\varepsilon_{\text {imp }}=2-4 \%$, а при максимальній напрузі змінного (втомного) навантаження $440 \mathrm{MПа}-$ за $\varepsilon_{\text {imp }}=3-5 \%$. Для стопу D16CzAT в порівнянні із середніми значеннями втомної довговічности у вихідному стані втомна довговічність після оброблення збільшується при $\sigma_{\max }=340 \mathrm{MПа} \mathrm{на} 11,6 \%$, при напруженні $\sigma_{\max }=370 \mathrm{MПа}-$ на $18,4 \%$, при напруженні $\sigma_{\max }=400 \mathrm{M \Pi а}-$ на $21,2 \%$. Відзначено також позитивний вплив на втомну довговічність довготривалої витримки після оброблення. Статистичними методами трансмісійної електронної мікроскопії досліджено вплив зміцнювальних фаз, таких як нанорозмірні частинки $\Theta-\mathrm{Al}_{2} \mathrm{Cu}$ i S-CuAl${ }_{2} \mathrm{Mg}$, на окремі стадії попереднього оброблення стопів, а також вплив їхньої кількости на втомну довговічність. Велику увагу приділено механізму утворення зародків втомного руйнування в приповерхневих ділянках зразків, для чого було застосовано аналітичні розрахунки й експериментальну методу ультразвукового ударного оброблення (УЗУО). Показано, що застосування УЗУО після УКН не впливає на втомну довговічність стопу 2024-Т351 за частоти втомного навантаження у 15 Гц, в той час як одна УЗУО збільшує втомну довговічність стопу. Робиться висновок, що одночасне застосування комплексних деформаційних впливів сприяє пришвидшенню релаксаційних процесів, які зменшують втомну довговічність.

Ключові слова: втомна довговічність, пластична деформація, імпульсне підвантаження, трансмісійна електронна мікроскопія, гетерогенні стопи алюмінію, ультразвукове ударне оброблення. 